Article

\title{
Disproportioned Performances of Protected Areas in the Beijing-Tianjin-Hebei Region
}

\author{
Hui Wen ${ }^{1}(0)$ Jiquan Chen ${ }^{2}\left(\right.$ and Zhifang Wang ${ }^{1, *}$ \\ 1 College of Architecture and Landscape, Peking University, Beijing 100871, China; huiwen@pku.edu.cn \\ 2 Department of Geography, Environment, and Spatial Sciences, Michigan State University, \\ East Lansing, MI 48823, USA; jqchen@msu.edu \\ * Correspondence: zhifangw@pku.edu.cn; Tel.: +86-010-62759003
}

Received: 15 July 2020; Accepted: 5 August 2020; Published: 9 August 2020

\begin{abstract}
Designing and managing protected areas (PAs) has always been value-based. While all PAs provide unique values in a region, it has not been documented if their functional contributions are proportional to their land area. A challenge also arises from the governance of PAs due to differences in supporting resources, legislations, conservation goals, and guidance. Using the Beijing-Tianjin-Hebei (BTH) region as our testbed, we designed a study to test the hypothesis that the functional contributions of 84 PAs, measured by various ecosystem service values, vulnerability and human footprint (Hf), are not proportional to land areas relative to the regional total. Disproportionate performances are partially due to the governance (i.e., national, provincial and local) and the dominant ecosystem type of each PA. We confirm our hypothesis that the functional contributions of PAs in the BTH region far exceed their total land area, with forested PAs performing better. The functional measures of PAs are highly correlated but not equally provided among PA types and under different governances. Both governance and PA type play significant roles in determining functional values and human influences, but no significant interactive influences were detected. Results from this study are updated shreds of evidence for promoting PAs as well as for establishing new PAs through the ongoing Ecological Red Lines program.
\end{abstract}

Keywords: protected areas; ecological red line; conservation objective; ecosystem services; governance; sustainability

\section{Introduction}

The concept of placing certain areas under protection was developed from the realization that there is unique and irreplaceable value in some landscapes [1]. The first official proposal to establish a protected area, led by Frederick Law Olmsted in 1865, argued that the Yosemite Valley and the Mariposa Big Tree Grove should be treated as parks so "the most certain value and gratification afforded by a park" could be experienced by people [2]. The proposal emphasized the importance of contact with the wilderness for human well-being, the effect of beautiful scenery on human perception, and the moral responsibility of governments to preserve regions of extraordinary natural beauty for the benefit of all people. The Organic Act of the US congress in 1916 officially established the National Park Service to "conserve the scenery and the natural and historic objects and the wildlife therein and to provide for the enjoyment of the same in such manner and by such means as will leave them unimpaired for the enjoyment of future generations". The act was largely influenced by John Muir's enthusiastic publications in 1913 and the persuasion of the government [3], as well as by public engagement (e.g., the establishment of the Sierra Club). This concept and associated practices have received global support from people and governments. By 2018, 8.3 million $\mathrm{km}^{2}(21 \%)$ of global lands were under various forms of protection, reflecting a continued increasing trend [4]. In Europe, 1.34 million $\mathrm{km}^{2}$ are 
under PAs $(>120,000)$ in 2018, which is $\sim 25 \%$ of its terrestrial area [5,6]. In China, where the concept was promoted only in the late $1970 \mathrm{~s}$, the total proportion of protected areas (PAs) increased from $0.13 \%$ $\left(12,700 \mathrm{~km}^{2}\right)$ in 1978 to $14.88 \%$ (1.47 million $\left.\mathrm{km}^{2}\right)$ in 2017 [7,8]—a 116-fold increase over 40 years.

There are several critical principles in establishing and maintaining PAs. First, it is a value-based approach, although the values are often loosely defined, vague, or single-minded [9,10]. Early PAs (e.g., the first PA in Sierra Nevada and the first national park in Yellowstone) were established mostly because of their unique geographical features (e.g., the giant sequoia-the largest tree species on the Earth, geothermal features, etc.) and aesthetic beauty. Many global PAs were established to preserve specific features (e.g., cultural heritage, archeological sites, wildlife habitat, rich species, or sites of endangered species, etc.). Secondly, PAs are designed for current and future benefit—sustainability [11,12]. They support human well-being and livelihoods by providing various ecosystem services (ES). Third, both the public and governments are responsible for the success of PA establishment and maintenance [13]. PAs are managed by different levels of government (e.g., county, provincial, or national). Increasingly, nonprofit and for-profit organizations (e.g., the Nature Conservancy) step up to promote PAs, sometimes becoming involved in management practices [14]. Clearly, both governance and human activities affect the service values of PAs. A crucial question here is whether current PAs can effectively provide multiple services to a society $[15,16]$ through different management [17].

Assessing and enhancing PA performances has long been a global effort [11]. Many studies have explored the provisions of ecosystem services generated by PAs [15], by arguing that their performances can be further improved [18]. A few studies also quantified performance on a regional scale $[19,20]$. Unfortunately, previous studies focus mostly on individual functions (e.g., species diversity), with limited efforts to address the independency of multiple values. While we do know that all PAs provide unique values, we do not have sufficient knowledge of their contributions to the overall values of a region, i.e., if these contributions are proportional to their land area. A challenge also arises from PA type and governance due to differences in supporting resources, legislations, conservation goals, guidance (i.e., missions), etc.

This study was motivated by the need to address these pressing issues, i.e., how key values of PAs under different governances and for different types in a region may vary. The lessons will be useful for revising the action plans of current PAs, as well as for designing future PAs [21]. After a quantitative analysis of the geographical structure of PAs, we calculate multiple value attributes. We use the Beijing-Tianjin-Hebei region (BTH) as our study site to address the aforementioned issues, with a central focus on the ecosystem values of PAs under different governances, with hope that the lessons learned can be used to improve future conservation network design in the BTH region. Specifically, we aim to (1) quantify the compositional and functional differences of PAs in the BHT region by governance and PA type, (2) examine whether the ecosystem services provided by PAs are proportional to their land areas, and (3) identify whether the functional values of PAs are equally provided under different governances and by PA type. The BTH region is one of the most populated areas in China (it includes China's capital-Beijing), with PAs that are assumed to provide water and soil retention [22]. We designed our study to answer the following questions: what conservation values are provided by PAs? Are PAs representative of BHT landscapes in supporting conservation values? How do their values vary by governance and PA type? We hypothesize that the functional contributions, measured by various ecosystem services (ESs), vulnerability and human footprint (Hf), are not proportional to land areas relative to the region's total. The disproportionate performances are partially due to the governance (i.e., national, provincial and local) and the dominant ecosystem type of each PA [23]. 


\section{Materials and Methods}

\subsection{Study Area}

The BTH region is located in the transitional zone between the Inner Mongolia Plateau and the North China Plain (Figure 1). The northwest is dominated by several mountains, which transition to plains in the southeast. Four ecological zones fall within the BTH region [24]: typical grasslands in the central and eastern Inner Mongolia Plateau, the Yanshan-Taihangshan mountain deciduous broad-leaved forest zone, urban agglomeration and sub-urban agricultural zone, and the agricultural zone.

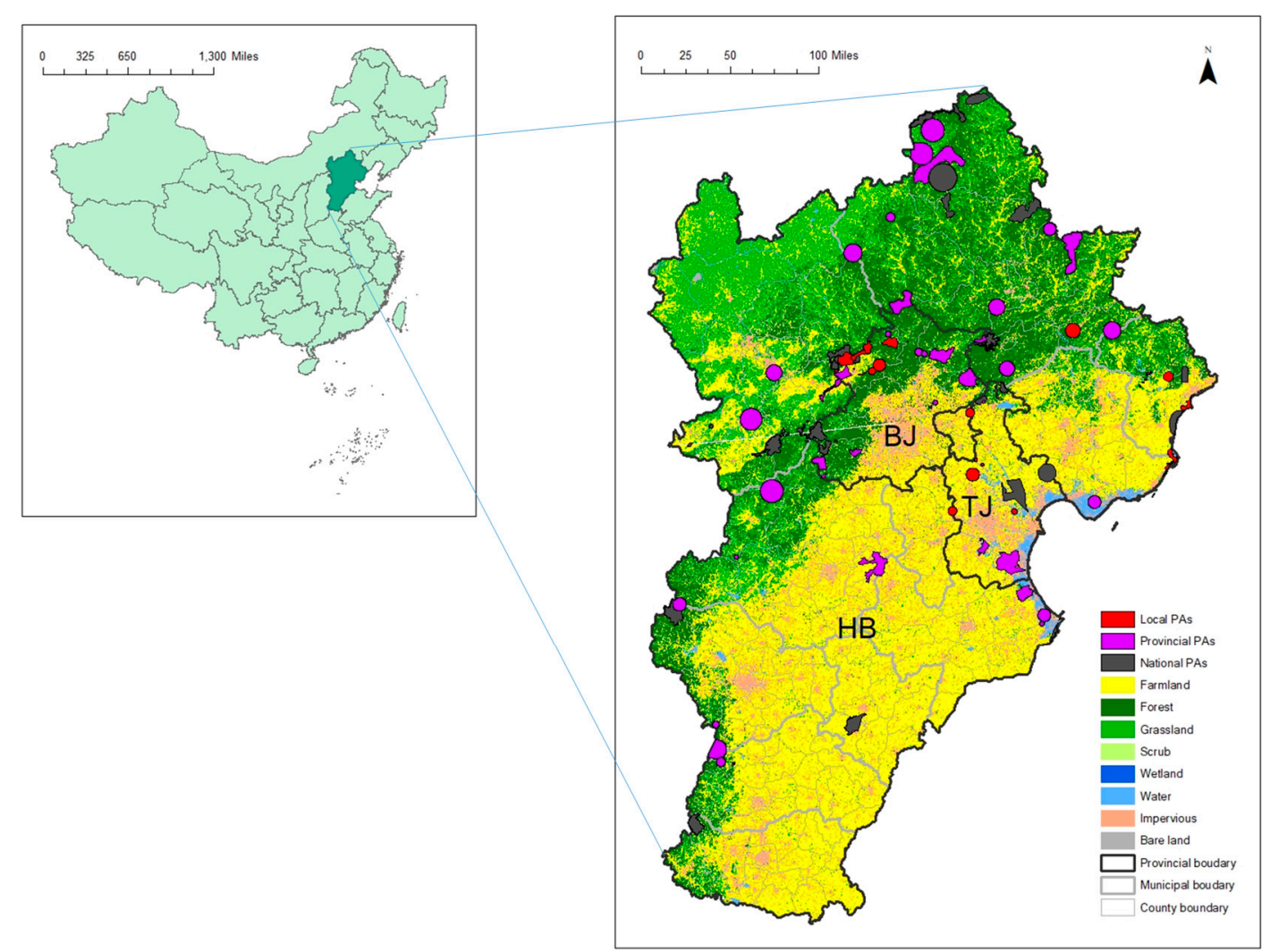

Figure 1. Location of Beijing-Tianjin-Hebei (BTH) region in eastern China and the spatial distributions of protected areas (PAs) overlaid on current land cover map. The PAs marked in black, purple and red are administrated by the national, provincial, and local government, respectively. BJ: Beijing. TJ: Tianjin; HB: Hebei.

\subsection{PAs within BTH}

Geographical location and associated information about PAs were extracted from the protected area database of National Forestry Administration [25], with additional statistics drawn from Wu et al. (2011) [9] and IUCN [26]. Within the database, some PAs were not described by their boundaries but by their total area and coordinates; we use symbols (Circles) to present these sites (Figure 1). These PAs are mostly distributed in mountainous areas in the northwest parts of the region. The 84 PAs include all the nature reserves and some of the forest parks, wetland parks and geological parks in BTH, covering $10,413 \mathrm{~km}^{2}$ (4.83\% of BTH) (Table 1). These PAs are administrated by national (23), provincial (42), and local (19) governments. The mean (STD) of national PAs $\left(93 \pm 129 \mathrm{~km}^{2}\right)$ is larger than provincial PAs $\left(74 \pm 123 \mathrm{~km}^{2}\right)$ and local PAs $\left(31 \pm 41 \mathrm{~km}^{2}\right)$. In terms of dominant cover type within each PA, forest PAs are the most common, in 44 PAs, which cover $5989 \mathrm{~km}^{2}$ (57.5\% of the total). On average, grassland-dominated PAs are the largest $\left(205 \mathrm{~km}^{2}\right)$, compared to forest $\left(75 \mathrm{~km}^{2}\right)$ and others $\left(40-52 \mathrm{~km}^{2}\right)$. Among the three provinces, 45 PAs are in Tianjin, 28 in Beijing and 11 in Hebei (Table 1). 
Table 1. Major statistics of the protected areas (PAs) by governance, dominant land cover type, and administrative jurisdiction in the Beijing-Tianjin-Hebei (BTH) region of China.

\begin{tabular}{|c|c|c|c|c|c|c|c|c|}
\hline \multirow{2}{*}{\multicolumn{2}{|c|}{ Categories }} & \multirow{2}{*}{ No } & \multicolumn{4}{|c|}{ Size $\left(\mathbf{k m}^{2}\right)$} & \multirow{2}{*}{$\begin{array}{l}\text { Total } \\
\left(\mathrm{km}^{2}\right)\end{array}$} & \multirow{2}{*}{$\begin{array}{c}\text { Portion } \\
(\%)\end{array}$} \\
\hline & & & Mean & Min & Max & STD & & \\
\hline \multirow{3}{*}{ Governance } & National & 23 & 93 & 3 & 506 & 129 & 3625 & 1.68 \\
\hline & Provincial & 42 & 74 & 1 & 507 & 123 & 5768 & 2.67 \\
\hline & Local & 19 & 31 & 1 & 140 & 41 & 1020 & 0.47 \\
\hline \multirow{4}{*}{$\begin{array}{l}\text { Dominant } \\
\text { Cover }\end{array}$} & Forest & 44 & 75 & 4 & 507 & 130 & 5896 & 2.73 \\
\hline & Grassland & 4 & 205 & 145 & 322 & 67 & 859 & 0.40 \\
\hline & Water & 13 & 52 & 1 & 348 & 101 & 2671 & 1.24 \\
\hline & Others & 23 & 40 & 10 & 344 & 95 & 987 & 0.46 \\
\hline \multirow{3}{*}{$\begin{array}{c}\text { Administrative } \\
\text { Authority }\end{array}$} & Beijing & 28 & 34 & 1 & 236 & 65 & 1864 & 0.86 \\
\hline & Tianjin & 45 & 47 & 6 & 344 & 123 & 1233 & 0.57 \\
\hline & Hebei & 11 & 104 & 4 & 507 & 128 & 7316 & 3.39 \\
\hline \multicolumn{2}{|c|}{ Overall } & 84 & 65 & 1 & 507 & 119 & 10,413 & 4.83 \\
\hline
\end{tabular}

\subsection{Validation of Performances}

Six indices as conservation objectives for regional importance were chosen. To justify the most appropriate conservation objectives, we first collected all relevant indices after reviewing over a hundred studies in BTH [27-30]. These indices were further evaluated and limited to six based upon typical indicator selection criteria of specificity, portable, measurability, sensitivity [31-33]. We calculated six indices as conservation objectives (COs). Four are ecosystem services: climate regulation $(\mathrm{Cr})$, water retention $(\mathrm{Wr})$, soil retention $(\mathrm{Sr})$, and wind prevention $(\mathrm{Wp})$. Two are for ecosystem vulnerability: soil erosion (Se) and desertification (De). We also calculated the human footprint index (Hf), which reflects the level of human activities as a stressor.

Water retention $(\mathrm{Wr})$ volume is calculated using the water balance equation in InVEST [34,35]; the amount of soil retention (Sr) and the sensitivity index of soil erosion (Se) are calculated by the RUSLE model [36,37]. Rainfall data is extracted from the 1-km monthly and annual precipitation data of the Human Geosystem Sedisystem Sedodatabase (http://www.data.ac.cn/). The yield ratio (K) comes from the literature [36,38]. Vegetation cover is quantified from the 1-km NDVI Monthly Synthesis (MOD09A1) of NASA's EOS data center for 2000-2009 (https://modis.gsfc.nasa.gov/). The vegetation type is from the 1-km global land cover of the University of Maryland (http://glcfapp.glcf.umd.edu:8080/esdi/index.jsp). Soil type and soil texture are derived from the 1:1 million soil space (94,000 plots) attribute data of the second National Land Survey by the Institute of Soil Science, CAS. The 90-m Digital Terrain Elevation Model (DEM) is from the International Scientific Data Mirror Network (http://www.gscloud.cn) of the Computer Network Information Center, CAS. The precipitation, runoff ratio, soil, DEM and MODIS data for 2000-2009 are scaled to 1-km as required input variables in our calculations.

The climate regulation service index ( $\mathrm{Cr}$ ) is extracted from the 1-km dataset for China, which was developed by the Institute of Geosciences and Resources, CAS, in 2015 [39]. The wind prevention (Wp) and Desertification (De) in 2015 are from the 250-m grid data of the Institute of Environmental Science Planning and Design [28]. The 2009 human ecological footprint index (Hf) is 1-km grid of Venter, which is based on population density, land cover type, accessibility, and electricity infrastructure to model human impacts [40]. All the data are synchronized to 1-km grid spatial data for BTH within the ArcGIS platform.

\subsection{Statistical Analysis}

To answer the above questions and achieve our study objectives, we performed statistical analyses to test two specific hypotheses: (1) there exist significant differences in the functional contributions of PAs, which are highly dependent on a PA's governance and type; and (2) the ratio between conservation 
objective values of the PAs $\left(\mathrm{CO}_{\mathrm{PA}}\right)$ and the total $\mathrm{CO}$ values of the $\mathrm{BTH}$ region $\left(\mathrm{CO}_{\text {total }}\right)$ is disproportional to their land areas $\left(\mathrm{A}_{\mathrm{PA}}\right)$, wherein $\mathrm{CO}_{\mathrm{PA}}: \mathrm{CO}_{\text {total }} \neq \mathrm{A}_{\mathrm{PA}}: \mathrm{A}_{\text {total }}$. Additionally, these disproportions vary by PA governance and type. Two-way analysis of variances (ANOVA) is performed to quantify the independent and interactive influences of governances (three levels) and types (forest and non-forest) on each CO measure. When interactive influences are not significant $(p>0.05)$, we proceed with the independent effects of governance and PA type for each objective value. As local management practices are based on multiple functions instead of individual ones, the $\mathrm{CO}$ values at county and planning unit (PU) levels may correlate with each other because of similar governance and PA type. There are 175 counties and 53,661 PUs within BTH; to provide useful evidence for future management, we calculated the correlations of $\mathrm{CO}$ values at PU level (i.e., $2 \times 2 \mathrm{~km}$ ).

\section{Results}

\subsection{Landscape Composition of the PAs and BTH}

Farmlands account for $45.5 \%$ of the BTH region, followed by forests (22.6\%), grasslands (18.1\%), and urban build-ups (10.0\%) (Figure 2). In comparison, PAs have a composition of $49.7 \%$ forests, $19.1 \%$ farmlands, and $18.1 \%$ grasslands. The proportion of water bodies within the PAs is much higher $(5.8 \%)$ than that of the region $(1.8 \%)$. Not surprisingly, the ratio of urban build-ups within the PAs $(4.7 \%)$ is less than half of the regional value. It is worth noting that the portion of wetlands within the PAs is small $(0.2 \%)$ but still several orders of the magnitude higher than that in the BTH (Figure 2). The landscape composition of PAs varies substantially by governance. National and local PAs have higher proportions of forests than provincial PAs, whereas water and grasslands are more common in provincial PAs than in national and local PAs. Relatively high proportions of farmland and built-up areas are also apparent in local PAs.

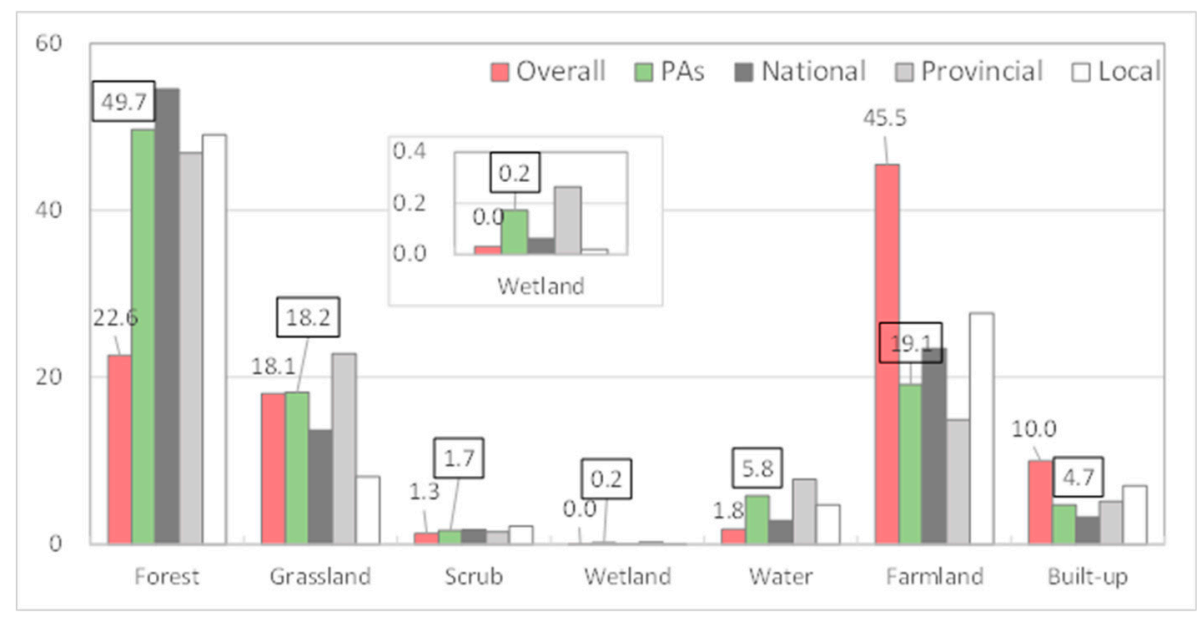

Figure 2. Landscape compositions (\%) of protected areas (PAs) in the BTH region by governance.

\subsection{Conservation Objective Value of the PAs and BTH}

The average unit value of five COs in the PAs is higher than those of $\mathrm{BTH}$; the De value is the same as for BTH region. As expected, the human footprint (Hf) of the PAs (14.1) is lower than that of BTH (18.4) (Table 2). Overall, PAs provide the highest relative soil retention (Sr) at $7.75 \%$ and the lowest relative contribution to water retention $(\mathrm{Wr})$ at $5.04 \%$. The human footprint (Hf) of all PAs is $3.70 \%$, which is far below that of the $4.83 \%$ of BTH land dedicated to PAs (Table 1 ). When compared among governances, the $\mathrm{CO}$ values per unit of land area in national PAs show higher amounts than those of the region, whereas provincial and local PAs provide similar or even lower values. The Hf of local PAs (16.0), for example, is surprisingly higher than that of national and provincial PAs (13.8-14.0), as well as the regional mean. Lower $\mathrm{CO}$ values in provincial PAs are coupled with their overall large 
sizes (Table 1), while local PAs have a substantially higher proportion of build-ups (Figure 2) and human footprint (Table 2). It is worth mentioning that $\mathrm{Wr}$ and $\mathrm{Sr}$ values per square kilometer at national and local levels are relatively higher than they are on a provincial level, while Se and De, the two vulnerability values, are higher on a provincial level than the other two levels. When PAs are divided into forest and non-forest groups, $\mathrm{CO}$ values (except De) are substantially higher in forest-dominated PAs, and Hf values are higher in non-forest PAs. In sum, differences in CO values and human footprint vary by governance and type; local PAs appear to be more influenced by human activities (e.g., build-ups).

Table 2. Values of six key conservation objectives and human footprint index (Hf) of the protected areas (PAs) in BTH region. The contribution of each conservation objective (CO) value is calculated as the $\mathrm{CO}$ per square kilometer (the measurement unit of climate regulation $(\mathrm{Cr})$ is $\mathrm{RMB}, \mathrm{Wr}$ is $\mathrm{m}^{3}$, and soil retention $(\mathrm{Sr})$ and wind prevention $(\mathrm{Wp})$ is ton; soil erosion (Se), desertification (De) and Hf are unitless; Se and De range 0-5.5 and 0-12.6, respectively; and Hf score ranges 12-96 within BTH), and its proportional contribution (\%) is calculated as the CO values of the PAs to the total CO values of BTH.

\begin{tabular}{|c|c|c|c|c|c|c|c|}
\hline & $\mathrm{Cr}$ & Wr & Sr & Wp & Se & De & Hf \\
\hline & $\times 10^{3}$ RMB (\%) & $\mathrm{m}^{3}(\%)$ & $t(\%)$ & $t(\%)$ & $(\%)$ & $(\%)$ & $(\%)$ \\
\hline \multicolumn{8}{|c|}{ Governance level } \\
\hline National & $2.0(2.75)$ & $751(1.84)$ & $104(2.85)$ & $0.22(2.38)$ & $3.4(2.43)$ & $3.8(2.09)$ & $14.0(1.28)$ \\
\hline Provincial & $1.8(4.05)$ & $686(2.68)$ & $92(4.02)$ & $0.19(3.26)$ & $3.7(4.14)$ & $4.9(4.22)$ & $13.8(2.01)$ \\
\hline Local & $1.7(0.65)$ & $753(0.52)$ & $114(0.88)$ & $0.13(0.39)$ & $3.3(0.65)$ & $3.8(0.56)$ & $16.0(0.41)$ \\
\hline \multicolumn{8}{|l|}{ PA Type } \\
\hline Forest & $2.4(5.35)$ & 773 (3.09) & $144(6.43)$ & $0.22(3.96)$ & $4.1(4.75)$ & $4.2(3.71)$ & $12.3(1.83)$ \\
\hline Non-forest & $1.2(2.09)$ & $639(1.96)$ & $37(1.32)$ & $0.15(2.07)$ & $2.8(2.47)$ & $4.6(3.16)$ & $16.4(1.87)$ \\
\hline \multicolumn{8}{|l|}{ Overall } \\
\hline PAs & $1.9(7.44)$ & $715(5.04)$ & $98(7.75)$ & $0.19(6.04)$ & $3.6(7.22)$ & $4.4(6.88)$ & $14.1(3.70)$ \\
\hline BTH & $1.2(100)$ & $686(100)$ & $61(100)$ & $0.15(100)$ & $2.4(100)$ & $4.4(100)$ & $18.4(100)$ \\
\hline
\end{tabular}

Our linear ANOVA indicates there is no significant interactive effect $(p<0.05)$ of governance (G) and PA type (E) on the six CO values and the human footprint (Table 3). The ANOVA models explained small amounts of variation, with $\mathrm{R}^{2}$ varying from 0.112 for De to 0.338 for $\mathrm{Sr}$. The eta squared values further indicated that PA type is the primary independent variable in comparisons with governance and the interactive effect $\left(E^{*} G\right)$. For $\mathrm{Cr}$, Sr and Se, PA type is responsible for $23.5 \%$, $33.1 \%$ and $21.5 \%$ of the total variance, respectively. For human footprint, both $\mathrm{G}$ and $\mathrm{E}$ are significant independent influences. For the main effect, the $p$-value for $\mathrm{Wp}$ is $<0.05$ (Table 3), with the partial least square indicating that $11 \%$ of the variation is from PA type and $8 \%$ from governance. For De, the type is only significant $(\sim 11 \%)$ for provincial and local PAs (Table 4$)$. As for Hf, both governance and type show significance; PA type contributes $31.8 \%$ of the variation, compared with $14.2 \%$ for governance. For eight significant contributions (bolded data in Table 3), there is a significant difference in $\mathrm{Cr}, \mathrm{Wr}$, $\mathrm{Sr}, \mathrm{Wp}$, and Se between forest and non-forest PAs with an overall variation of $654 \mathrm{RMB}, 103 \mathrm{~m}^{3}, 62 \mathrm{t}$, $0.052 \mathrm{t}$, and 0.788 , respectively (Table 4). Whereas for $\mathrm{Wp}$, there are significant differences between national and local PAs, with an average difference of $0.057 \mathrm{t}$, and for De between provincial and local PAs with a difference of 0.736 . 
Table 3. Statistics of the two-way ANOVA on CO valuesper unit land area with three levels of governance and two levels of PA type $(n=84)$. "E": dominant ecosystem type (forest and non-forest). “G": Governance (national, provincial and local). " $\mathrm{E}^{*} \mathrm{G}$ ”: Interactive effect of $\mathrm{E}$ and $\mathrm{G}$.

\begin{tabular}{|c|c|c|c|c|c|}
\hline COs measure & Adjusted $R^{2}$ & Term & $\mathbf{F}$ & $p$-Value & Partial Eta Squared \\
\hline \multirow{3}{*}{$\begin{array}{l}\text { Climate regulation } \\
\qquad(\mathrm{Cr})\end{array}$} & \multirow{3}{*}{0.243} & $\mathrm{E}$ & 24.01 & 0.000 & 0.235 \\
\hline & & $\mathrm{G}$ & 2.560 & 0.084 & 0.062 \\
\hline & & $E^{*} G$ & 0.304 & 0.738 & 0.008 \\
\hline \multirow{3}{*}{$\begin{array}{l}\text { Water retention } \\
\qquad(\mathrm{Wr})\end{array}$} & \multirow{3}{*}{0.204} & $\mathrm{E}$ & 19.94 & 0.000 & 0.204 \\
\hline & & G & 0.573 & 0.566 & 0.014 \\
\hline & & $E^{*} G$ & 0.245 & 0.783 & 0.006 \\
\hline \multirow{3}{*}{$\begin{array}{l}\text { Soil retention } \\
(\mathrm{Sr})\end{array}$} & \multirow{3}{*}{0.338} & $\mathrm{E}$ & 38.53 & 0.000 & 0.331 \\
\hline & & G & 1.684 & 0.192 & 0.041 \\
\hline & & $E^{*} G$ & 0.219 & 0.749 & 0.007 \\
\hline \multirow{3}{*}{$\begin{array}{l}\text { Wind prevention } \\
\qquad(\mathrm{Wp})\end{array}$} & \multirow{3}{*}{0.130} & $\mathrm{E}$ & 9.675 & 0.002 & 0.110 \\
\hline & & $\mathrm{G}$ & 3.483 & 0.035 & 0.082 \\
\hline & & $E^{*} G$ & 0.633 & 0.534 & 0.016 \\
\hline \multirow{3}{*}{$\begin{array}{l}\text { Soil erosion } \\
\text { (Se) }\end{array}$} & \multirow{3}{*}{0.241} & $\mathrm{E}$ & 21.31 & 0.000 & 0.215 \\
\hline & & G & 2.705 & 0.073 & 0.065 \\
\hline & & $E^{*} G$ & 2.101 & 0.129 & 0.051 \\
\hline \multirow{3}{*}{$\begin{array}{l}\text { Desertification } \\
\text { (De) }\end{array}$} & \multirow{3}{*}{0.112} & $\mathrm{E}$ & 0.260 & 0.614 & 0.003 \\
\hline & & G & 4.727 & 0.012 & 0.108 \\
\hline & & $E^{*} G$ & 3.109 & 0.050 & 0.074 \\
\hline \multirow{3}{*}{$\begin{array}{l}\text { Human footprint } \\
\text { (Hf) }\end{array}$} & \multirow{3}{*}{0.330} & $\mathrm{E}$ & 36.38 & 0.000 & 0.318 \\
\hline & & G & 6.454 & 0.003 & 0.142 \\
\hline & & $E^{*} G$ & 0.765 & 0.469 & 0.019 \\
\hline
\end{tabular}

Table 4. Statistical tests of conservation objective (CO) differences ( $t$-test) when governance or type has a significant independent influence on each $\mathrm{CO}$ value at $p<0.05$ (shown in Table 3). "F-NF": test between forest and non-forest PAs. "N-L": test between national and local PAs; "P-L" test between provincial-local PAs. "MD": mean difference.

\begin{tabular}{cccc}
\hline COs Measure & Pairs & MD & $p$-Value \\
\hline Climate regulation (Cr) & F-NF (E) & 654 & 0.000 \\
\hline Water retention (Wr) & F-NF (E) & 103 & 0.000 \\
\hline Soil retention (Sr) & F-NF (E) & 62 & 0.000 \\
\hline \multirow{2}{*}{ Wind prevention (Wp) } & F-NF (E) & 0.052 & 0.002 \\
& N-L (G) & 0.057 & 0.041 \\
\hline Soil erosion (Se) & F-NF (E) & 0.788 & 0.000 \\
\hline Desertification (De) & P-L (G) & 0.736 & 0.015 \\
\hline & F-NF (E) & -5.243 & 0.000 \\
Human footprint (Hf) & P-L(G) & -5.229 & 0.019 \\
& N-L(G) & -5.810 & 0.002 \\
\hline
\end{tabular}

\subsection{Functional and Structural Contributions of PAs}

Among the 23 national PAs, 12 are classified as forest (F-N) and 11 as non-forest (NF-N). For provincial PAs, 20 are forest (F-P) and 22 are non-forest (NF-P). Local PAs include 12 forest (F-L) and 7 non-forest (NF-L). The ratios of $\mathrm{CO}$ values from the PAs to those of regional means (i.e., $\left.\mathrm{CO}_{\mathrm{PA}}: \mathrm{CO}_{\text {total }}\right)$ are higher than the ratios of land area (i.e., $\left.\mathrm{A}_{\mathrm{PA}}: \mathrm{A}_{\text {total }}\right)$. Although there exist exceptions and variations by governance and PA type, our hypothesis is accepted for all seven measures of PA functions (Figure 3). The majority of forest PAs (in green) had higher functional contributions than their land portions, with many showing near a 2:1 ratio (e.g., $\mathrm{Cr}, \mathrm{Sr}$ and Se) (Figure 3a,c,d). For De and Hf, 
the functional contributions of forest PAs are about 1-2 times of their area contributions (Figure 3e,f). For Wr, all forest PAs show near equal functional contributions (Figure 3b). The only PA showing a low ratio of Wr and Sr is a Xiaoshan volcanic geological heritage provincial protected area. For non-forest PAs, there appear to be no clear-cut conclusions. Most ratios for $\mathrm{Cr}$ and $\mathrm{Sr}$ are lower than their area proportion (Figure $3 \mathrm{a}, \mathrm{c}$ ), and their ratios for $\mathrm{Wr}$ and $\mathrm{Hf}$ are similar to the area ratios (Figure $3 \mathrm{~b}, \mathrm{~d}, \mathrm{f}$ ). However, the De ratios are 1-2 times their area ratios (Figure 3e).

Governance also plays an important role in the relationships between $\mathrm{CO}_{\mathrm{PA}}: \mathrm{CO}_{\text {total }}$ and $\mathrm{A}_{\mathrm{PA}}: \mathrm{A}_{\text {total }}$. National forest PAs (green triangle) have ratios above the 1:1 line, with a few exceptions such as Baixian Mountain national PA and Horn ditch provincial PA. For Sr, most ratios below the 1:1 line are provincial non-forest PAs (red circles). For De of the non-forest PAs (red), provincial PAs (circle) are above the 1:2 line, while all national PAs (triangular) are below the 1:1 line. Local PAs show similar ratios, albeit the variations are much higher. 

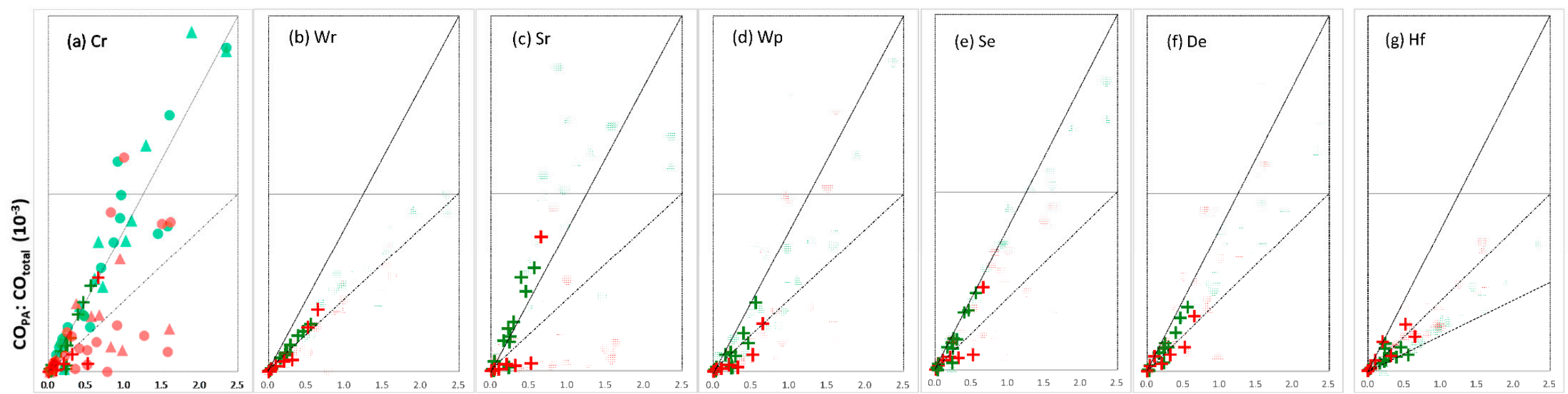

$A_{\mathrm{PA}}: \mathrm{A}_{\text {total }}\left(10^{-3}\right)$

$\triangle \mathrm{F}-\mathrm{N} \bullet \mathrm{F}-\mathrm{P}+\mathrm{F}-\mathrm{L} \triangle \mathrm{NF}-\mathrm{N} \bullet \mathrm{NF}-\mathrm{P}+\mathrm{NF}-\mathrm{L}$

$\cdots-1: 1$ line $-1: 2$ line $\quad \cdots-\cdots .0 .5: 1$ line

Figure 3. Relationships between $\mathrm{CO}_{\mathrm{PA}}: \mathrm{CO}_{\text {total }}$ and $\mathrm{A}_{\mathrm{PA}}: \mathrm{A}_{\text {total }}$ for the $\mathrm{CO}$ measures for six groups of PAs in the BTH region. The 1:1 line indicates that PAs functional contributions are equal to their land area-based contributions. The 2:1 line indicates that the functional contribution is double that of area contributions. Note that the 0.5:1 line for human footprint indicates half of humane influences. 


\subsection{Correlations among ES Measures}

There exist variable correlations in both magnitude and direction among the seven performances of the PAs at three levels: PA, county and planning unit (PU) (Table 5). Five correlations were not significant: De vs. Sr and De vs. Hf at PA level, Hf vs. De at both PA and county level, and Sr vs. Wr at county level. Overall, the correlations at county level are higher than those at PA and PU level.

Table 5. Correlation coefficient of determination $\left(R^{2}\right)$ for 21 paired relationships among six measures of conservation objectives (COs) and the human impact index (Hf) at three levels. (I) PA level (n = 84), (II) county level ( $\mathrm{n}=175)$, and (III) planning unit (PU) level $(\mathrm{n}=53,661) .{ }^{* *}$ indicates a significant level of $0.01, *$ indicates a significant level of 0.05 .

\begin{tabular}{|c|c|c|c|c|c|c|c|}
\hline & $\mathrm{Cr}$ & $\mathrm{Wr}$ & $\mathrm{Sr}$ & Wp & Se & $\mathrm{De}$ & $\mathrm{Hi}$ \\
\hline $\mathrm{Cr}$ & 1 & & & & & & \\
\hline $\mathrm{Wr}$ & $\begin{array}{l}\text { I: } 0.636^{* *} \\
\text { II: }-0.016 \\
\text { III: } 0.154^{* *}\end{array}$ & 1 & & & & & \\
\hline $\mathrm{Sr}$ & $\begin{array}{l}\text { I: } 0.779 * * \\
\text { II: } 0.896^{* *} \\
\text { III: } 0.640^{* *}\end{array}$ & $\begin{array}{l}\text { I: } 0.716^{* *} \\
\text { II: } 0.145 \\
\text { III: } 0.375^{* *}\end{array}$ & 1 & & & & \\
\hline $\mathrm{Wp}$ & $\begin{array}{l}\text { I: } 0.460 * * \\
\text { II: } 0.650 * * \\
\text { III: } 0.415^{* *}\end{array}$ & $\begin{array}{l}\text { I: } 0.233^{*} \\
\text { II: }-0.198^{* *} \\
\text { III: }-0.083^{* *}\end{array}$ & $\begin{array}{l}\text { I: } 0.379^{* *} \\
\text { II: } 0.502 * * \\
\text { III: } 0.334^{* *}\end{array}$ & 1 & & & \\
\hline Se & $\begin{array}{l}\text { I: } 0.731^{* *} \\
\text { II: } 0.780^{* *} \\
\text { III: } 0.607^{* *}\end{array}$ & $\begin{array}{l}\text { I: } 0.365^{* *} \\
\text { II: }-0.335^{* *} \\
\text { III: } 0.048^{* *}\end{array}$ & $\begin{array}{l}\text { I: } 0.783^{* *} \\
\text { II: } 0.802 * * \\
\text { III: } 0.739 * *\end{array}$ & $\begin{array}{l}\text { I: } 0.524^{* *} \\
\text { II: } 0.419 * * \\
\text { III: } 0.396^{* *}\end{array}$ & 1 & & \\
\hline De & $\begin{array}{l}\text { I: } 0.024 \\
\text { II: } 0.5311^{* *} \\
\text { III: } 0.410^{* *}\end{array}$ & $\begin{array}{l}\text { I: }-0.315^{* *} \\
\text { II: }-0.609^{* *} \\
\text { III: }-0.227^{* *}\end{array}$ & $\begin{array}{l}\text { I: } 0.076 \\
\text { II: } 0.525^{* *} \\
\text { III: } 0.436^{* *}\end{array}$ & $\begin{array}{l}\text { I: } 0.249 * \\
\text { II: } 0.392 * * \\
\text { III: } 0.319^{* *}\end{array}$ & $\begin{array}{l}\text { I: } 0.532 * * \\
\text { II: } 0.902 * * \\
\text { III: } 0.813^{* *}\end{array}$ & 1 & \\
\hline $\mathrm{Hi}$ & $\begin{array}{l}\text { I: }-0.637^{* *} \\
\text { II: }-0.565^{* *} \\
\text { III: }-0.420^{* *}\end{array}$ & $\begin{array}{l}\text { I: }-0.336^{* *} \\
\text { II: }-0.156^{*} \\
\text { III: } 0.061^{*}\end{array}$ & $\begin{array}{l}\text { I: }-0.538^{* *} \\
\text { II: }-0.443^{* *} \\
\text { III: }-0.400^{* *}\end{array}$ & $\begin{array}{l}\text { I: }-0.418^{* *} \\
\text { II: }-0.440^{* *} \\
\text { III: }-0.319^{* *}\end{array}$ & $\begin{array}{l}\text { I: }-0.577^{* *} \\
\text { II: }-0.164^{*} \\
\text { III: }-0.320 * *\end{array}$ & $\begin{array}{l}\text { I: }-0.194 \\
\text { II: } 0.017 \\
\text { III: }-0.162 * *\end{array}$ & 1 \\
\hline
\end{tabular}

At the three levels, four pairs of relationships present medium-high correlation $\left(R^{2}>0.5\right)$ : Cr-Sr, $\mathrm{Cr}-\mathrm{Se}$, Sr-Se and De-Se. Six pairs show medium correlation, with $\mathrm{R}^{2}$ of 0.3-0.65: $\mathrm{Cr}-\mathrm{Wp}, \mathrm{Cr}-\mathrm{Hi}, \mathrm{Sr}-\mathrm{Hi}$, $\mathrm{Sr}-\mathrm{Wp}, \mathrm{Wp}-\mathrm{Se}$ and Wp-Hf. Negative correlations are found for Cr-Wr, Wr-Wp, Wr-Se, Wr-Hi and De-Hi. Climate regulation has clear correlations with other $\mathrm{CO}$ measures, except a low correlation with water retention at county and PU levels, and a very low correlation with desertification at PA level. Except for soil retention, all other relationships with water retention at PU level are low or even negative. Wr-Wp and Wr-Se in PAs are positive, while for the other two levels they are negative or show a very low positive correlation. Human footprint shows low or negative relationships with other $\mathrm{CO}$ measures, with the highest $\mathrm{R}^{2}$ value found for $\mathrm{Cr}$.

\section{Discussion}

\subsection{Values of Protected Areas}

Designing and managing protected areas has always been value-based. This is done by reducing or restricting human activities. Through estimating ecosystem services, vulnerability and human influences of 84 PAs within the BTH region, we confirm our hypothesis that the functional contributions of the PAs in the BTH region far exceed their total land area (Figure 3). Some ecosystem services are double of their area portion, though with exceptions. These estimates provide us promising evidence supporting the success of PAs in BTH, which were developed mostly within the past three decades [24], albeit the first PA in China was established in 1956. 
Regardless of the overall disproportionate performance of PAs, there exist substantial differences among the seven measures we examined, as well as the PA types. Compared to the $4.83 \%$ area contribution, all six indicators of the PAs provide $5 \%-7.8 \%$ contribution, while the human impact of the PAs (3.7\%) is lower than that of the region. Most PAs worldwide were initially designed to protect biological diversity amid an increasing recognition of their other functions such as enhancing ecosystem services and regulating regional climate [41,42]. Within the BTH, 72 of the 84 PAs were originally designed to conserve species. Through testing a hypothesis on the area-function ratio, we demonstrate that PAs provide more value than other land cover types within the BTH region. The average values of all four ecosystem services are higher for PAs compared with the regional means. This is coupled with lower human influences within the PAs (Table 2). However, we found that non-forest PAs did not always provide expected values when compared with regional means (Figure 3). This is especially true for their low contributions to climate regulation, soil regulation, and wind prevention. A possible reason is that BTH is in a temperate deciduous forest zone [18]. Restored non-forest PAs from croplands within the BTH would function differently than forests.

Finally, it is worth reiterating the correlations among functional measures of PAs because ecosystem services, vulnerability and human influences are not provided equally by each PA. Four pairs of metrics (Sr-Se, Cr-Sr, Cr-Se and De-Se) are highly correlated. While the high correlation of Sr-Se is likely because they are predicted with the same model, $\mathrm{Cr}$ 's correlations with all other indicators (e.g., $\mathrm{Wp}$ and $\mathrm{De}$ ) are reasonable because both wind erosion and desertification are related to climatic changes. In sum, PAs provide multiple functions in addition to the preservation of biodiversity. Integrating ecosystem functions and ecosystem services for assessing existing PAs and establishing new PAs is necessary in order to promote collaborative conservations and enhance the efficiency of conservation and management.

\subsection{The Role of Governance and Type}

Our second hypothesis is also accepted, i.e., both governance and PA type play significant roles in determining functional values and human influences. However, our initial premise was that governance might dominate over PA type in explaining variations because national PAs receive more resources from the government and have more restricted rules for human activities. However, this is proven untrue by our results. For $\mathrm{Cr}$, Sr and $\mathrm{Hf}$, PA type explains $20-33 \%$ of the total variation, whereas governance explains $8 \%-11 \%$. The more important role of PA type compared with governance, meanwhile, emphasizes that the initial decision in establishing PA type is very crucial for its subsequent functions. Another surprise in this study is the insignificant interactions between governance and PA type. Forest PAs are one of the most protected ecosystems on a global level because of their great contributions to climate mitigation $[43,44]$. Our results confirm these continued efforts on the part of forest PAs within the BTH region.

The proportion of forests and water bodies in the PAs within the BTH is more than twice the regional average, while the proportion of grassland is similar to the regional mean. Plausibly, forest PAs accounts for the largest proportion, and water bodies account for the largest proportion in provincial protection spaces. Water bodies, meanwhile, are less sensitive to the area of protection than the others. In general, the trend among forest groups is obvious compared with non-forest groups, and forests are more concentrated even among human influence factors. The points in the forest group are basically sensitive to area increases, and certain characteristics, especially soil preservation and climate regulation, increase even more than twice the proportion of the increase in area. Nevertheless, this trend varies with different objectives, especially within the vulnerable group.

The governance, nonetheless, plays a significant role in $\mathrm{Wp}$ and De, especially on a local level. The overall function of national PAs is higher than those of provincial and local PAs (Table 2). The primary reason for this may be higher supporting resources and stricter regulations, such as access to and activities allowed inside the parks. On the other hand, the Wr and Sr of local PAs are higher than those of provincial and national PAs due to a stronger interest in reducing wind and soil erosions 
through management. This suggests that management practices (and regulations) applied to national PAs can potentially be applied to provincial and local PAs. Meanwhile, local PAs are often closer to human populations or accessed more by residents. This means that they provide spaces and other functions to people that may not be replaceable by provincial and national PAs [45]. The overall higher services of $\mathrm{Wr}$ and $\mathrm{Sr}$ from local PAs are direct evidence for promoting more local PAs for human well-being. More research is needed to integrate social and economic elements on smaller scales [46].

Localized protected areas are closer to human settlements and have higher human impact. Their contribution to key ecosystem functions on a regional scale is generally lower, but this does not mean it is not important [47]. In holistic national or regional spatial planning, these localized protected areas scattered around human settlements not only provide diversified value to meet human needs but also contribute a continuous flow and network for wholesome ecosystem functions in the region, such as the ecosystem services and functions in this study. In large-scale spatial planning, it is necessary to recognize their roles and combine their contribution. For these close-knit protected areas, more research is needed to confirm their significance, as well as modes and patterns that are more meaningful on local, regional and national levels. Future studies should further identify and optimize the design of such spaces in the study area.

\subsection{Implications for Future Research}

This study sheds light on the importance of existing PAs in supporting the six conservation objects in BTH and achieving multifunctionality of PAs, which is increasingly important in China [48]. Effective planning and governance of PAs are much more complicated than we revealed in this paper, and we would suggest that future research addresses the following issues further. First, biodiversity is the primary goal of most current PAs, and more studies are needed to understand whether biodiversity has been achieved and what the relationships between biodiversity and other ecological objectives are. Second, aesthetic and recreational values have not been identified as important in many studies of BTH but have been highlighted in regional studies from other countries $[49,50]$. Third, conflicts between PAs and other land uses are pressing issues to be addressed. Conservation areas in BTH have been and will be in strong competition with other land uses such as urbanization. Maintaining the quantity and the quality of PAs must be placed in the context of other land uses and developments.

Achieving multiple conservation objectives including biodiversity, ecosystem functions and services is expected when designing and developing alternative management plans for PAs. Here, we provide updated evidence for PAs' performances within BTH. Lessons learned from this study will be useful for governments who are gearing up to increase the number of PA (i.e., from current $18 \%$ to $20 \%$ in the future). The evolving philosophy exists to enhance cumulative values through integrating existing and future PAs [27]; for example, the ongoing Ecological Red Lines project in China calls for multi-objective, systematic ecological conservation planning [51]. With rapid changes to the global climate and escalating human activities, many unprecedented processes were not foreseen by pioneer conservationists and policymakers when managing and designing PAs [52]. As global ecosystem degradations continue [53-55], public support for promoting PAs and adopting new conservation strategies is mounting. Pressing issues include addressing the conflicts between PAs and other land uses, increasing the quantity and quality of PAs, sustaining ecosystem services, and offsetting the effects of ecosystem degradation [56]. Our findings shed a bright light on these issues, at least for PAs within the BTH region.

\section{Conclusions}

Through quantifying the performances of protected areas (PAs) in the BTH region, we confirmed the effectiveness of PAs that provide overall high ecosystem service values, low vulnerability and reduced human footprint. Theses functional measures are not proportional to their land areas relative to the regional total. The majority of forest PAs had higher functional contributions than their land portions, with many showing near a 2:1 ratio. Disproportionate performances are found to vary by 
governance (i.e., national, provincial and local) and the dominant ecosystem type of PAs. These PAs provide the highest relative soil retention ( $\mathrm{Sr}$ ) at $7.75 \%$ and the lowest relative contribution to water retention (Wr) at $5.04 \%$, which is still higher than the $4.83 \%$ of land areas dedicated to PAs. Meanwhile, the human footprint of all PAs is $3.70 \%$. Surprisingly, we found governance and type of PA determined PA performances independently (versus their interactive effects), with national forested PAs performing the best. This study provides updated evidence supporting the concept of and continued efforts in promoting PAs. Results from this study can be useful for ongoing efforts in increasing the number, size and quality of protected areas within the BTH region, as well as for developing sustainable PAs elsewhere, achieving multiple conservation objectives through the engagement of all stakeholders.

Author Contributions: Conceptualization, J.C. and H.W.; formal analysis, H.W.; funding acquisition, Z.W.; methodology, J.C. and H.W.; supervision, Z.W.; Writing-original draft, H.W.; Writing-review and editing, J.C. and Z.W. All authors have read and agreed to the published version of the manuscript.

Funding: This study is partially funded by the National Natural Science Foundation of China (51678002) and the Major Science and Technology Program for Water Pollution Control and Treatment (2012ZX07307001-03, 2013ZX07304-001-6). J.C. is supported by NASA's LCLUC program for the Mongolia Plateau (80NSSC20K0410). Kristine Blakeslee of Michigan State University provided valuable editing on the language of this manuscript.

Acknowledgments: The authors are grateful to Jixi Gao at Nanjing Institute of Environmental Science, Renqiang $\mathrm{Li}$ at the Institute of Geographic Sciences and Natural Resources Research of Chinese Academy of Science, Junhui Liu at Chinese Research Academy of Environmental science for their valuable data and technological support.

Conflicts of Interest: The authors declare no conflict of interest.

\section{References}

1. Soulé, M.E. What is conservation biology? Bioscience 1985, 35, 727-734.

2. Olmsted, F.L. Yosemite and the Mariposa Grove: A Preliminary Report. 1865. Available online: www. yosemite.ca.us/library/olmsted/report.html (accessed on 20 April 2020).

3. Muir, J. The Story of My Boyhood and Youth; Sierra Club: San Francisco, CA, USA, 2004.

4. Protected Planet Report 2016; UNEP-WCMC and IUCN: Cambridge, UK; Gland, Switzerland, 2016.

5. EEA (European Environmental Agency). An Introduction to Europe's Protected Areas. Available online: https://www.eea.europa.eu/themes/biodiversity/europe-protected-areas (accessed on 6 May 2020).

6. Nila, M.U.S.; Beierkuhnlein, C.; Jaeschke, A.; Hoffmann, S.; Hossain, M.L. Predicting the effectiveness of protected areas of natura 2000 under climate change. Ecol. Process. 2019, 8, 13. [CrossRef]

7. Jing, W.; Junping, S.; Lei, S.; Ning, L.; Zhong, M.; Xiuxiang, M. Natural reserve system of China: Current status, problems and prospect. China Popul. Resour. Environ. 2016, 26, 270-273.

8. Gao, G.; Xu, M.; Zou, C. Development achievement of natural conservation in 70 years of New China. China Environ. Manage. 2019, 11, 25-29.

9. Wu, R.; Zhang, S.; Yu, D.W.; Zhao, P.; Li, X.; Wang, L.; Yu, Q.; Ma, J.; Chen, A.; Long, Y. Effectiveness of China's nature reserves in representing ecological diversity. Front. Ecol. Environ. 2011, 9, 383-389. [CrossRef]

10. Egoh, B.; Rouget, M.; Reyers, B.; Knight, A.T.; Cowling, R.M.; van Jaarsveld, A.S.; Welz, A. Integrating ecosystem services into conservation assessments: A review. Ecol. Econ. 2007, 63, 714-721. [CrossRef]

11. Font, X.; Garay, L.; Jones, S. Sustainability motivations and practices in small tourism enterprises in european protected areas. J. Clean Prod. 2016, 137, 1439-1448. [CrossRef]

12. Hiwasaki, L. Community-based tourism: A pathway to sustainability for Japan's protected areas. Soc. Nat. Resour. 2006, 19, 675-692. [CrossRef]

13. Plummer, R.; Fennell, D.A. Managing protected areas for sustainable tourism: Prospects for adaptive co-management. J. Sustain. Tour 2009, 17, 149-168. [CrossRef]

14. Graham, J.; Amos, B.; Plumptre, T.W. Governance Principles for Protected Areas in the 21st Century; Institute on Governance: Ottawa, ON, Canada, 2003.

15. Eastwood, A.; Brooker, R.; Irvine, R.J.; Artz, R.R.E.; Norton, L.R.; Bullock, J.M.; Ross, L.; Fielding, D.; Ramsay, S.; Roberts, J.; et al. Does nature conservation enhance ecosystem services delivery? Ecosyst. Serv. 2016, 17, 152-162. [CrossRef] 
16. Butchart, S.H.M.; Scharlemann, J.P.W.; Evans, M.I.; Quader, S.; Arico, S.; Arinaitwe, J.; Balman, M.; Bennun, L.A.; Bertzky, B.; Besancon, C.; et al. Protecting important sites for biodiversity contributes to meeting global conservation targets. PLoS ONE 2012, 7, e32529. [CrossRef] [PubMed]

17. Veldhuis, M.P.; Ritchie, M.E.; Ogutu, J.O.; Morrison, T.A.; Beale, C.M.; Estes, A.B.; Mwakilema, W.; Ojwang, G.O.; Parr, C.L.; Probert, J.; et al. Cross-boundary human impacts compromise the serengeti-mara ecosystem. Science 2019, 363, 1424-1428. [CrossRef] [PubMed]

18. Zhang, Y.; Li, J.; Zhou, Z. Exploring expedient protected area for ecosystem services: Decision-making method with a new algorithm. Sustainability 2019, 11, 5599. [CrossRef]

19. Castro, A.; Martinlopez, B.; Lopez, E.; Plieninger, T.; Alcarazsegura, D.; Vaughn, C.C.; Cabello, J. Do protected areas networks ensure the supply of ecosystem services? Spatial patterns of two nature reserve systems in Semi-arid Spain. Appl. Geogr. 2015, 60,1-9. [CrossRef]

20. Mukul, S.A.; Sohel, M.S.I.; Herbohn, J.; Inostroza, L.; König, H. Integrating ecosystem services supply potential from future land-use scenarios in protected area management: A bangladesh case study. Ecosyst. Serv. 2017, 26, 355-364. [CrossRef]

21. Johnson, C.N.; Balmford, A.; Brook, B.W.; Buettel, J.C.; Galetti, M.; Lei, G.; Wilmshurst, J.M. Biodiversity losses and conservation responses in the Anthropocene. Science 2017, 356, 270-274. [CrossRef]

22. Yang, Y.Y.; Zheng, H.; Xu, W.H.; Zhang, L.; Ouyang, Z.Y. Temporal changes in multiple ecosystem services and their bundles responding to urbanization and ecological restoration in the Beijing-Tianjin-Hebei metropolitan area. Sustainability 2019, 11, 2079. [CrossRef]

23. Guerra, C.A.; Rosa, I.M.D.; Pereira, H.M. Change versus stability: Are protected areas particularly pressured by global land cover change? Landsc. Ecol. 2019, 34, 2779-2790. [CrossRef]

24. Fu, B.; Liu, G. China Ecological Zoning Study; Science Press: Beijing, China, 2013; pp. 46-53.

25. China Nature Reserve Specimen Sharing Platform. Available online: http://www.papc.cn/ (accessed on 24 March 2019).

26. KBA Partnership. World Database of Key Biodiversity Areas. Available online: http://www. keybiodiversityareas.org/home (accessed on 19 November 2018).

27. MEP (Ministry of Environmental Protection); CAS (Chinese Academy of Science). National Ecological Function Zoning (Revised); CAS: Beijing, China, 2015.

28. Liu, J.; Ma, S.; Gao, J.; Zou, C.; Wang, J.; Liu, Z.; Wang, L. Delimiting the ecological conservation redline at regional scale: A case study of Beijing-Tianjin-Hebei region. China Environ. Sci. 2018, 38, 2652-2657.

29. Wang, J.; Zhou, W.; Pickett, S.T.A.; Yu, W.; Li, W. A multiscale analysis of urbanization effects on ecosystem services supply in an urban megaregion. Sci. Total Environ. 2019, 662, 824-833. [CrossRef]

30. Zhitao, X.; Pengfei, C.; Shijian, Z. Change of ecological service in Beijing-Tianjin-Hebei region in recent 10 years. Bull. Soil Water Conserv. 2018, 38, 220-226.

31. Hattam, C.; Atkins, J.P.; Beaumont, N.; Börger, T.; Böhnke-Henrichs, A.; Burdon, D.; De Groot, R.; Hoefnagel, E.; Nunes, P.A.; Piwowarczyk, J. Marine ecosystem services: Linking indicators to their classification. Ecol. Indic. 2015, 49, 61-75. [CrossRef]

32. van Oudenhoven, A.; Petz, K.; Alkemade, R.; Hein, L.; de Groot, R.S. Framework for systematic indicator selection to assess effects of land management on ecosystem services. Ecol. Indic. 2012, 21, 110-122. [CrossRef]

33. Link, J.S.; Yemane, D.; Shannon, L.J.; Coll, M.; Shin, Y.; Hill, L.; Borges, M.D.F. Relating marine ecosystem indicators to fishing and environmental drivers: An elucidation of contrasting responses. ICES J. Mar. Sci. 2010, 67, 787-795. [CrossRef]

34. Budyko, M.I. Climate and Life; Academic Press: San Diego, CA, USA, 1971.

35. Sharp, R.; Chaplin-Kramer, R.; Wood, S.; Guerry, A.; Tallis, H.; Ricketts, T. InVEST Version 3.3.2 User's Guide; Federal Highway Administration: Washington, DC, USA, 2016.

36. Zhang, K.; Peng, W.; Yang, H. Soil erodibility and its estimation for agricultural soil in China. Acta Pedol. Sin. 2007, 44, 7-13. [CrossRef]

37. Wischmeier, W.H.; Smith, D.D. Predicting Rainfall Rrosion Losses-A Guide to Conservation Planning; Department of Agriculture: Washington, DC, USA, 1978.

38. Williams, J.R.; Jones, C.A.; Dyke, P.T. A modeling approach to determining the relationship between erosion and soil productivity. Trans. ASAE 1984, 27, 129-144. [CrossRef] 
39. Xu, X. China Spatial Data Set Terrestrial Ecosystem Services Value in China; Resource and Scientific Data Center of CAS: Beijing, China, 2018; Volume 2019.

40. Venter, O.; Sanderson, E.W.; Magrach, A.; Allan, J.R.; Beher, J.; Jones, K.R.; Possingham, H.P.; Laurance, W.F.; Wood, P.; Fekete, B.M.; et al. Sixteen years of change in the global terrestrial human footprint and implications for biodiversity conservation. Nat. Commun. 2016, 7, 12558. [CrossRef]

41. Doak, D.F.; Bakker, V.J.; Goldstein, B.E.; Hale, B. What is the future of conservation. Trends Ecol. Evol. 2014, 2, 77-81. [CrossRef]

42. Lafortezza, R.; Chen, J. The provision of ecosystem services in response to global change: Evidences and applications. Environ. Res. 2016, 147, 576-579. [CrossRef]

43. Rodriguez, N.; Armenteras, D.; Retana, J. Effectiveness of protected areas in the Colombian Andes: Deforestation, fire and land-use changes. Reg. Environ. Chang. 2013, 13, 423-435. [CrossRef]

44. Vackar, D.; Harmackova, Z.V.; Kankova, H.; Stupkova, K. Human transformation of ecosystems: Comparing protected and unprotected areas with natural baselines. Ecol. Indic. 2016, 66, 321-328. [CrossRef]

45. Garnett, S.T.; Burgess, N.D.; Fa, J.E.; Fernandez-Llamazares, A.; Molnar, Z.; Robinson, C.J.; Watson, J.E.M.; Zander, K.K.; Austin, B.; Brondizio, E.S.; et al. A spatial overview of the global importance of indigenous lands for conservation. Nat. Sustain. 2018, 1, 369-374. [CrossRef]

46. He, L.; Shen, J.; Zhang, Y. Ecological vulnerability assessment for ecological conservation and environmental management. J. Environ. Manag. 2018, 206, 1115-1125. [CrossRef] [PubMed]

47. Wintle, B.A.; Kujala, H.; Whitehead, A.; Cameron, A.; Veloz, S.; Kukkala, A.; Moilanen, A.; Gordon, A.; Lentini, P.E.; Cadenhead, N.C.R.; et al. Global synthesis of conservation studies reveals the importance of small habitat patches for biodiversity. Proc. Natl. Acad. Sci. USA 2019, 116, 909-914. [CrossRef] [PubMed]

48. Wang, Z. Evolving landscape-urbanization relationships in contemporary China. Landsc. Urban Plan. 2018, 171, 30-41. [CrossRef]

49. Southon, G.E.; Jorgensen, A.; Dunnett, N.; Hoyle, H.; Evans, K.L. Biodiverse perennial meadows have aesthetic value and increase residents' perceptions of site quality in urban green-space. Landsc. Urban Plan. 2017, 158, 105-118. [CrossRef]

50. Richards, D.R.; Warren, P.H.; Moggridge, H.L.; Maltby, L. Spatial variation in the impact of dragonflies and debris on recreational ecosystem services in a floodplain wetland. Ecosyst. Serv. 2015, 15, 113-121. [CrossRef]

51. MEP (Ministry of Environmental Protection); NDRC (National Development and Reform Commission). Manual of Ecological Eed Line Zoning. 2017. Available online: http://www.mee.gov.cn/gkml/hbb/bgt/201707/ W020170728397753220005.pdf (accessed on 10 January 2019).

52. Mengist, W.; Soromessa, T.; Feyisa, G.L. A global view of regulatory ecosystem services: Existed knowledge, trends, and research gaps. Ecol. Process. 2020, 9, 1-14. [CrossRef]

53. Barnosky, A.D.; Hadly, E.A.; Gonzalez, P.; Head, J.; Polly, P.D.; Lawing, A.M.; Eronen, J.T.; Ackerly, D.D.; Alex, K.; Biber, E.; et al. Merging paleobiology with conservation biology to guide the future of terrestrial ecosystems. Science 2017, 355, eaah4787. [CrossRef]

54. Lanzas, M.; Hermoso, V.; De-Miguel, S.; Bota, G.; Brotons, L. Designing a network of green infrastructure to enhance the conservation value of protected areas and maintain ecosystem services. Sci. Total Environ. 2019, 651, 541-550. [CrossRef]

55. WWF (World Wildlife Foundation). Living Planet Report 2016: Risk and Resilience in a New Era; WWF International: Gland, Switzerland, 2016.

56. Garcia-Llorente, M.; Harrison, P.A.; Berry, P.; Palomo, I.; Gomez-Baggethun, E.; Iniesta-Arandia, I.; Montes, C.; Garcia Del Amo, D.; Martin-Lopez, B. What can conservation strategies learn from the ecosystem services approach? Insights from Ecosystem assessments in two Spanish protected areas. Biodivers. Conserv. 2018, 27, 1575-1597. [CrossRef]

(C) 2020 by the authors. Licensee MDPI, Basel, Switzerland. This article is an open access article distributed under the terms and conditions of the Creative Commons Attribution (CC BY) license (http://creativecommons.org/licenses/by/4.0/). 